\title{
LC-MS/MS DETECTION OF UNALTERED GLUCURONOCONJUGATED METABOLITES OF METANDIENONE
}

Argitxu Esquivel a,b, Oscar J. Pozo a, Lorena Garrostas a, Georgina Balcells ${ }^{\text {a,b }}$, Cristina Gómez $^{\text {a }}$, Aristotelis Kotronoulas ${ }^{\text {a,c }}$, Jesús Joglar ${ }^{\text {c }}$, Rosa Ventura* a,b.

a) Bioanalysis Research group, IMIM, Hospital del Mar Medical Research Institute, Doctor Aiguader 88, 08003 Barcelona, Spain

b) Department of Experimental and Health Sciences, Universitat Pompeu Fabra, Doctor Aiguader 88, 08003 Barcelona, Spain.

c) Department of Biological Chemistry and Molecular Modeling, Instituto de Química Avanzada de Cataluña, Consejo Superior de Investigaciones Científicas ((IQAC-CSIC), Jordi Girona 18-26, 08034 Barcelona, Spain.

*Corresponding author:

Rosa Ventura Alemany

Bioanalysis Research Group

IMIM, Hospital del Mar Medical Research Institute

Doctor Aiguader 88

08003 Barcelona, Spain

Tel. 34933160471

Fax 34933160499

E-mail: rventura@imim.es 


\section{Abstract}

The aim of this study was to evaluate the direct detection of glucuronoconjugated metabolites of metandienone (MTD) and their detection times. Metabolites resistant to enzymatic hydrolysis were also evaluated. Based on the common mass spectrometric behavior of steroid glucuronides, three liquid chromatography-mass spectrometry (LCMS/MS) strategies were applied for the detection of unpredicted and predicted metabolites: precursor ion scan (PI), neutral loss scan (NL), and theoretical selected reaction monitoring (SRM) methods. Samples from four excretion studies of MTD were analyzed for both the detection of metabolites and the establishment of their detection times. Using PI and NL methods, seven metabolites were observed in postadministration samples. SRM methods allowed for the detection of thirteen glucuronide metabolites. The detection times, measured by analysis with a SRM method, were between one and twenty two days. The metabolite detected for the longest time was 18nor-17 $\beta$-hydroxymethyl-17 $\alpha$-methyl-5 $\beta$-androsta-1,4,13-triene-3-one-17-glucuronide.

One metabolite was resistant to hydrolysis with $\beta$-glucuronidase, however it was only detected in urine up to four days after administration. The three glucuronide metabolites with the highest retrospectivity were identified by chemical synthesis or mass spectrometric data, and although they were previously reported, this is the first time that analytical data of the intact phase II metabolites are presented for some of them. The LC-MS/MS strategies applied have demonstrated to be useful for detecting glucuronoconjugated metabolites of MTD, including glucuronides resistant to enzymatic hydrolysis which cannot be detected by conventional approaches.

Keywords: Doping, metabolism, glucuronoconjugates, LC-MS/MS, metandienone. 


\section{Introduction}

Anabolic androgenic steroids (AAS) are prohibited in sports due to their performance enhancing properties and adverse health effect. AAS are the most important group of forbidden substances detected in doping control analyses, reflecting the wide use of these drugs by athletes ${ }^{[1]}$. Therefore, there is a continuous need to improve the detection capabilities. AAS suffer extensive metabolism, and they are excreted in urine mainly as phase II metabolites, following the metabolic pathways of testosterone ${ }^{[2-4]}$. Metabolites conjugated with glucuronic acid are the most abundant phase II metabolites for AAS, however, it is known that for many AAS a significant part of the metabolic profile remains unknown ${ }^{[2,4]}$. The metabolites excreted for a long period in urine (long-term metabolites) are the most useful markers of the administration.

Studies on steroid metabolism have been performed using gas chromatography-mass spectrometry (GC-MS) or liquid chromatography-tandem mass spectrometry (LCMS/MS) after specific hydrolysis of the samples to release the phase I metabolites ${ }^{[2,4-}$ 6]. Glucuronoconjugates have been detected after enzymatic hydrolysis with $\beta$ glucuronidase and, therefore, only conjugates hydrolyzable in the conditions used have been systematically studied. In addition, underestimation of some of the glucuronoconjugates may be produced, due to the low efficiency of the $\beta$-glucuronidase hydrolysis depending on the structure of the glucuronide and to the presence of enzyme inhibitors in the urine matrix ${ }^{[7]}$.

LC-MS allows for the direct detection of phase II metabolites and its application has resulted in the identification of previously unreported conjugated metabolites, such as glucuronides, sulfates or cysteinyl conjugates ${ }^{[8-15]}$. Glucuronoconjugated metabolites of 
stanozolol and testosterone which are poorly or not hydrolysed using $\beta$-glucuronidase enzymes have been detected using LC-MS/MS strategies $\left.{ }^{[8,} 9\right]$. Metabolites of testosterone resistant to enzymatic hydrolysis were identified as $6 \beta$-hydroxyandrosterone and $6 \beta$-hydroxy-etiocholanolone conjugated at the $3 \alpha$-hydroxy group ${ }^{[8]}$. Based on the common ionization and collision induced dissociation (CID) behavior of steroid glucuronides ${ }^{[16]}$, a series of open detection methods based on neutral loss (NL) and precursor ion (PI) scan have been proposed to detect them by LC-MS/MS ${ }^{[8]}$. Selected reaction monitoring (SRM) methods using characteristic ion transitions of potential steroid phase II metabolites have been also used in previous works to detect new phase II metabolites ${ }^{[11,12,17]}$.

Metandienone (MTD) is one of the most frequently detected AAS, and its metabolism has been widely studied $[2,3,5,6,12,18-24]$. The most important metabolites are glucuronoconjugates that have been studied using $\beta$-glucuronidase hydrolysis. Another important metabolite is $6 \beta$-hydroxy-MTD, detected in free form ${ }^{[18]}$. As indicated above, $\beta$-glucuronidase resistant metabolites, containing a $6 \beta$-hydroxy group have been recently described for testosterone.

The aim of this paper was to directly detect glucuronoconjugated metabolites, including metabolites resistant to $\beta$-glucuronidase hydrolysis, in samples collected after administration of MTD. Different LC-MS/MS strategies will be evaluated to detect glucuronides and, the detection times of the glucuronides detected will be also studied.

\section{Experimental}

\subsection{Chemicals and reagents}


17 $\beta$-methyl-5 $\beta$-androst-1-ene-3 $\alpha, 17 \alpha$-diol (epimetendiol) and 18-nor-17,17-dimethyl$5 \beta$-androsta-1,13-dien-3 $\alpha$-ol (18-nor-dimethyl) were supplied by NMI Australian Government (Pymble, Australia). Methyltestosterone from Toronto Research Chemicals (Toronto, Canada), and, testosterone-d3 17-glucuronide and androsterone-d4 3-glucuronide from NMI Australian Government (Pymble, Australia), were used as internal standards (IS).

Methanol (MeOH) (LC grade), acetonitrile (ACN) (LC gradient grade), formic acid (LC/MS grade), tert-butyl-methyl ether (TBME), ammonium formate, acetic acid (glacial), disodium hydrogen phosphate, sodium hydrogen phosphate, sodium carbonate, sodium hydrogen carbonate, potassium carbonate and ammonium iodide were purchased from Merck (Darmstadt, Germany). Toluene, acetobromo- $\alpha-D-$ glucuronic acid methyl ester, silver carbonate, lithium hydroxide and 2mercaptoethanol were obtained from Sigma-Aldrich Química S.A. (Madrid, Spain). $\beta$ glucuronidase enzyme (type K12, E. coli) was supplied from Roche Diagnostics GmbH (Mannheim, Germany). The derivatization reagent $N$-methyl- $N$-trimethylsilyltrifluoroacetamide (MSTFA) was from Karl Bucher Chemische Fabrik GmbH (Waldstetten, Germany).

Milli Q quality water was obtained using a Milli-Q purification system (Millipore Ibérica, Barcelona, Spain). The Sep-Pak Vac RC C18 (500mg) cartridge were purchased from Waters (Milford, Massachusetts, USA).

\subsection{Excretion studies}


Urine samples obtained from four excretion studies involving the administration of a single oral dose of MTD to healthy Caucasian male volunteers were analyzed: subject A, 50 years, $99 \mathrm{~kg}, 5 \mathrm{mg}$; subject B, 27 years, $60 \mathrm{~kg}, 7.5 \mathrm{mg}$; subject C, 25 years, $65 \mathrm{~kg}, 5$ $\mathrm{mg}$; subject D, 57 years, $90 \mathrm{~kg}, 5 \mathrm{mg}$.

The clinical protocols were approved by the Local Ethical Committee (CEIC-IMAS, Institut Municipal d'Assistència Sanitària, Barcelona, Spain). All subjects participating in the studies gave their written informed consent.

The urine samples were collected before administration and after administration up to 72 hours (Subject A), 240 hours (Subject B), 31 days (Subject C) and 45 days (Subject D). All urine samples were kept frozen at $\leq 20^{\circ} \mathrm{C}$ until analysis.

\subsection{Sample preparation}

\subsubsection{Detection of glucuronide metabolites}

\subsection{1.a. Direct detection of the total fraction of glucuronides}

A liquid-liquid extraction was performed to remove the free fraction. TBME $(6 \mathrm{~mL})$ was added to $5 \mathrm{~mL}$ of urine, after the addition of $20 \mu \mathrm{L}$ of an IS solution (d3-T-G at 1 $\mu \mathrm{g} / \mathrm{mL}$ and $\mathrm{d} 4-$ And-G at $5 \mu \mathrm{g} / \mathrm{mL})$. After agitation and centrifugation (2200g, 5min), the organic layer was discarded. The aqueous phase was passed through a C18 column, previously conditioned with $2 \mathrm{~mL}$ of $\mathrm{MeOH}$ and $2 \mathrm{~mL}$ of water. The columns were washed with $2 \mathrm{~mL}$ of water and, then, the analytes were eluted with $2 \mathrm{~mL}$ of $\mathrm{MeOH}$. Four aliquots of $5 \mathrm{~mL}$ of the same urine were extracted and, the eluates were collected together. They were evaporated to dryness in a water bath at $50^{\circ} \mathrm{C}$ and reconstituted 
with $200 \mu \mathrm{L}$ of $\mathrm{ACN}$ :water $(1: 9, \mathrm{v} / \mathrm{v})$. A volume of $10 \mu \mathrm{L}$ was injected into the LCMS/MS.

\subsection{1.b Detection of glucuronides resistant to enzymatic hydrolysis with $\beta$-glucuronidase}

Urine sample $(5 \mathrm{~mL})$ was passed through a $\mathrm{C} 18$ cartridge and treated as described in section 2.2.1.a. The eluate was evaporated to dryness under a nitrogen stream in a water bath at $50^{\circ} \mathrm{C}$. Then, the extract was reconstituted with $1 \mathrm{~mL}$ of sodium phosphate buffer (1M, pH 7), $30 \mu \mathrm{L}$ of $\beta$-glucuronidase solution were added (type K12, E. coli) and sample was hydrolysed for $2.5 \mathrm{~h}$ at $55^{\circ} \mathrm{C}$. After cooling to room temperature, $250 \mu \mathrm{L}$ of a $5 \%(\mathrm{w} / \mathrm{v})$ potassium carbonate solution was added to obtain a $\mathrm{pH}$ value of 9.5. Extraction was performed twice with $6 \mathrm{~mL}$ of TBME. The organic layers were discarded, and the aqueous phase was passed through a C18 column, after the addition of $20 \mu \mathrm{L}$ of an IS solution (d3-T-G at $1 \mu \mathrm{g} / \mathrm{mL}$ and $\mathrm{d} 4-A n d-\mathrm{G}$ at $5 \mu \mathrm{g} / \mathrm{mL}$ ). Conditioning, washing and elution were the same as described in the first step. The eluate was evaporated to dryness and re-dissolved in $150 \mu \mathrm{L}$ of $\mathrm{ACN}$ :water $(1: 9, \mathrm{v} / \mathrm{v})$, and $10 \mu \mathrm{L}$ were injected into the LC-MS/MS system.

In order to detect glucuronides resistant to enzymatic hydrolysis, results obtained with and without the addition of the enzyme were compared.

\subsubsection{Evaluation of the detection times of glucuronide metabolites in excretion study urines using $L C-M S / M S$}

A method previously described was used ${ }^{[25]}$. After addition of $20 \mu \mathrm{L}$ of the IS solution (d3-T-G at $1 \mu \mathrm{g} / \mathrm{mL}$ and d4-And-G at $5 \mu \mathrm{g} / \mathrm{mL}$ ), urine sample $(2 \mathrm{~mL}$ ) was passed through a $\mathrm{C} 18$ cartridge and treated as described in section 2.2.1.a. The eluate was 
evaporated to dryness, reconstituted with $200 \mu \mathrm{L}$ of a solution of $\mathrm{ACN}$ :water (1:9, v/v), and injected $(10 \mu \mathrm{L})$ into the LC-MS/MS.

\subsubsection{Evaluation of the detection times of free and glucuronide metabolites in excretion study urines by GC-MS/MS}

A method previously described was used ${ }^{[26]}$. IS (100 ng/mL of methyltestosterone) was added to $2.5 \mathrm{~mL}$ of urine sample and the $\mathrm{pH}$ was made neutral with $1 \mathrm{~mL}$ of sodium phosphate solution (1M, pH 7). Enzymatic hydrolysis was performed with $30 \mu \mathrm{L}$ of $\beta$ glucuronidase (type K12, E. coli) and incubating at $55^{\circ} \mathrm{C}$ for 1 h. After hydrolysis, 200 $\mathrm{mg}$ of sodium hydrogen carbonate/sodium carbonate $(1 / 2, \mathrm{w} / \mathrm{w})$ were added and the mixture was extracted with $6 \mathrm{~mL}$ TBME. After centrifugation $(2200 \mathrm{~g}, 5 \mathrm{~min})$, the organic layer was evaporated to dryness. The extract was left under vacuum for $60 \mathrm{~min}$ and derivatized with $50 \mu \mathrm{L}$ of MSTFA: $\mathrm{NH}_{4} \mathrm{I}: 2-$ mercaptoethanol $(1000: 2: 6, \mathrm{v} / \mathrm{w} / \mathrm{v})$ by heating at $60^{\circ} \mathrm{C}$ for $20 \mathrm{~min}$, and then $2 \mu \mathrm{L}$ were analyzed by GC-MS/MS.

\subsection{Synthesis of glucuronide metabolites}

Glucuronides of epimetendiol and 18-nor-dimethyl were qualitatively synthesized using a previously described procedure ${ }^{[27]}$. Briefly, $40 \mu \mathrm{g}$ of epimetendiol $(0.13 \mu \mathrm{mol}, 1$ equivalent) or $40 \mu \mathrm{g}$ of 18 -nor-dimethyl $(0.14 \mu \mathrm{mol}, 1$ equivalent $)$ were dissolved in 0.5 $\mathrm{mL}$ of toluene. For epimetendiol $521 \mu \mathrm{g}(1.31 \mu \mathrm{mol}, 10$ equivalents $)$ and, for 18-nordimethyl $552 \mu \mathrm{g}$ (1.39 $\mu \mathrm{mol}, 10$ equivalents) of acetobromo- $\alpha$-D-glucuronic acid methyl ester were added, followed by $500 \mu \mathrm{g}$ of $\mathrm{Ag}_{2} \mathrm{CO}_{3}$. After 3 days of vigorous stirring at $75^{\circ} \mathrm{C}$, the mixture was cooled to room temperature, filtered and evaporated to dryness under vacuum. The solid residue was dissolved in $0.5 \mathrm{~mL}$ of $\mathrm{MeOH}$ and 0.5 
$\mathrm{mL}$ of aqueous $\mathrm{LiOH} 1 \mathrm{M}$ and left under stirring at room temperature for $28 \mathrm{~h}$ before solvent removal. The product was neutralized with $0.5 \mathrm{~mL}$ of acetic acid $1 \mathrm{M}$.

Presence of the synthesized glucuronide was confirmed by LC-MS/MS analysis.

\subsection{LC-MS/MS instrumental conditions}

Chromatographic separations were carried out on a Waters Acquity UPLC ${ }^{\mathrm{TM}}$ system (Waters Corporation, Mildford, MA, USA) using an Acquity BEH $\mathrm{C}_{18}$ column $(2.1 \mathrm{~mm}$ $\times 100 \mathrm{~mm}$ i.d., $1.7 \mu \mathrm{m}$ particle size). The column temperature was set to $45^{\circ} \mathrm{C}$. The mobile phase was a mixture of $0.01 \%$ formic acid and $1.0 \mathrm{mM}$ ammonium formate in water (solvent A) and $0.01 \%$ formic acid and $1.0 \mathrm{mM}$ ammonium formate in ACN:water (95:5, v/v) (solvent B). The elution was done in gradient mode and the percentage of organic solvent (solvent B) was changed as follows: 0min, 20\%; 4min, $20 \%$; 30min, 40\%; 32min, 70\%; 34min, 95\%; 36min, 95\%; 37min, 20\%; 40min, $20 \%$. The flow rate was $0.3 \mathrm{~mL} / \mathrm{min}$.

Detection was performed in a triple quadrupole $\left(\mathrm{XEVO}^{\mathrm{TM}} \mathrm{TQMS}\right)$ mass spectrometer equipped with an orthogonal Z-spray-electrospray ionization source (ESI) (all from Waters Corporation). Drying gas as well as nebulizing gas was nitrogen. The desolvation gas flow was set to $1200 \mathrm{~L} / \mathrm{h}$, and the cone gas flow was $50 \mathrm{~L} / \mathrm{h}$. The nitrogen desolvation temperature was $450^{\circ} \mathrm{C}$, and the source temperature was $150^{\circ} \mathrm{C}$.

For the detection of new glucuronide metabolites of MTD, NL and PI scan and, SRM methods described in Table 1 (Methods 1, 2 and 3) were applied to pre- and postadministration samples. 
To evaluate the detection times of the glucuronide metabolites in excretion study samples, a SRM method was optimized (Table 2). Three specific ion transitions were monitored for each glucuronide metabolite. Optimization of the cone voltage (CV) and the collision energy (CE) for each ion transition was performed by analysis of postadministration urine extracts. Moreover, for the selection of the best transitions for each metabolite, the presence of any interfering substance at the retention time (RT) of the metabolites was verified by the analysis of ten blank urine samples obtained from different healthy volunteers.

\subsection{GC-MS/MS instrumental conditions}

The study was performed on an Agilent 7890A gas chromatograph equipped with a 7693 autosampler, a split/splitless capillary inlet and an Agilent 7000A Series Triple Quadrupole GC/MS. The whole system was controlled by the MassHunter workstation software. The GC was equipped with a capillary column (HP-Ultra1 $16.5 \mathrm{~m} \times 0.2 \mathrm{~mm}$ id with a $0.11 \mathrm{~lm}$ film thickness) from J\&W (Agilent Technologies, USA). The gas chromatograph temperature was ramped as follows: initial temperature $185{ }^{\circ} \mathrm{C}$, increased at $25^{\circ} \mathrm{C} / \mathrm{min}$ to $230^{\circ} \mathrm{C}$, then at $10^{\circ} \mathrm{C} / \mathrm{min}$ to $290^{\circ} \mathrm{C}$, then at $70^{\circ} \mathrm{C} / \mathrm{min}$ to $310^{\circ} \mathrm{C}$, and maintained at the final temperature for $1.5 \mathrm{~min}$. The transfer line and inlet were kept at $280^{\circ} \mathrm{C}$. A $2 \mu \mathrm{L}$ aliquot of the final extract was injected in split mode (split ratio 1:10). Nitrogen was used as collision gas at a flow rate of $1.5 \mathrm{~mL} \mathrm{~min}^{-1}$, and helium as a quenching gas at a flow rate of $2.25 \mathrm{~mL} \mathrm{~min}^{-1}$. The electron ionization source was kept at $230^{\circ} \mathrm{C}$ and the quadrupoles at $150^{\circ} \mathrm{C}$. Data acquisition was performed in SRM mode (Table 1, Method 4)

\section{Results}




\subsection{Detection of potential metabolites of MTD conjugated with glucuronic acid.}

The common ionization and fragmentation of the glucuronoconjugated metabolites of AAS $^{[16]}$ allowed defining different LC-MS/MS analytical approaches to directly detect glucuronide metabolites of MTD (Table 1, Methods 1, 2 and 3). These methods were applied to samples collected before and after administration of MTD. The metabolites detected are described in Table 2.

In the total ion chromatograms (TIC) of PI and NL scan methods only a peak at the RT of MVII was detected. However, when extracted ion chromatograms (XIC) of different predicted precursor ions were evaluated, seven peaks were detected, five using the NL scan methods (metabolites MI, MII, MVII, MVIII and MXI) and, five using the PI scan methods (metabolites MII, MIII, MV, MVII and MXI) (Table 2). These peaks were not observed in pre-administration samples.

Using the SRM method, thirteen potential glucuronoconjugated metabolites (MI to MXIII) were detected in post-administration samples (Table 2). No peaks at the same RT were present in pre-administration samples.

\subsection{Detection of MTD metabolites conjugated with glucuronic acid resistant to hydrolysis with $\beta$-glucuronidase.}

Urine samples collected after administration of MTD were processed as described in experimental section and analyzed by the same LC-MS/MS strategies (Table 1, Methods 1, 2 and 3) to evaluate if some of the glucuronide metabolites were resistant to hydrolysis with $\beta$-glucuronidase. Using NL and PI scan methods no peaks were detected in the TIC and XIC. However, SRM analysis allowed the detection of one 
glucuronide resistant to hydrolysis with $\beta$-glucuronidase, MXIII (RT, $2.04 \mathrm{~min}$ ). This peak had a similar intensity in samples treated with and without enzymatic hydrolysis, showing that the metabolite was not hydrolyzed using $\beta$-glucuronidase enzymes.

\subsection{Evaluation of the detection times of the glucuronide metabolites in excretion study urines}

Samples of four excretion studies were analyzed by LC-MS/MS using an optimized SRM method (Table 2) to evaluate the detection times achieved by monitoring the thirteen potential glucuronide metabolites. Examples of chromatograms of the metabolites detected in samples of excretion study $\mathrm{C}$ at different collection times are shown in Figure 1. Detection times of the different metabolites are detailed in Table 2 and summarized in Figure 2. Metabolites MII, MI and MVII showed the longest retrospectivity. Metabolite MII was detected in all samples collected in the A and B excretion studies (up to 3 and 10 days, respectively), and up to 14 and 22 days in the $\mathrm{C}$ and D studies. Metabolite MI was detected up to 3, 5, 4 and 11 days in the A, B, C and D excretion studies and, metabolite MVII up to 3, 6, 4 and 9 days, respectively. The detection time of MXIII, metabolite resistant to hydrolysis with $\beta$-glucuronidase, was 3 days in the $\mathrm{A}$ and $\mathrm{C}$ excretion studies and, 4 and 2 days in the $\mathrm{B}$ and $\mathrm{D}$, respectively.

\subsection{Confirmation of the identity of the glucuronide metabolites}

The confirmation of the identity of metabolites with highest retrospectivity (MI, MII and MVII) was performed.

The molecular mass (MM) of MII was $474 \mathrm{Da}$ and, thus, the MM of the phase I metabolite was $298 \mathrm{Da}$, which corresponds to the structure of MTD with an oxidation 
or with a dehydration and a hydroxylation, which were metabolites previously reported. Because these phase I metabolites are not commercially available, the synthesis was not possible. The product ion mass spectrum of $[\mathrm{M}+\mathrm{H}]^{+}$showed clear ions at $m / z 121,135$, 147, 171 and 173, and the most abundant ion was $m / z$ 121, characteristic of 1,4-diene3-keto steroids. The analysis by SRM method of post-administration samples showed an additional product ion at $\mathrm{m} / \mathrm{z} 269$ (corresponding to the loss of glucuronide and formaldehyde group) at the same RT than the other ion transitions (Figure 3), allowing the identification of MII as the metabolite resulting from a dehydration and an

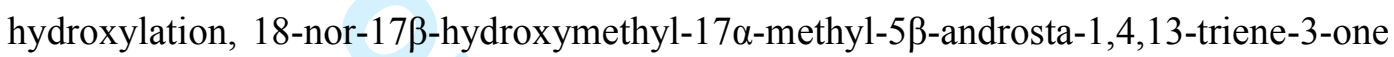
17 -glucuronide ${ }^{[6]}$.

The synthesis of the glucuronide of 18-nor-dimethyl revealed a peak at the RT of metabolite MI with the same product ion mass spectra confirming the identity of this metabolite as 18-nor-17,17-dimethyl-5 $\beta$-androsta-1,13-dien-3 $\alpha$-ol $3 \alpha$-glucuronide (18nor-dimethyl 3 $\alpha$-glucuronide) (Figure 3). The structure of MVII metabolite was confirmed as $17 \beta$-methyl-5 $\beta$-androst-1-ene-3 $\alpha, 17 \alpha$-diol $3 \alpha$-glucuronide (epimetendiol $3 \alpha$-glucuronide) by the synthesis of the glucuronide from the phase I metabolite (Figure 3). The product ion spectra of synthesized products are presented in Figure $4^{[23]}$.

\subsection{GC-MS/MS detection of MTD metabolites}

For comparison purposes, the three identified glucuronide metabolites were analyzed by GC-MS/MS as aglycones after enzymatic hydrolysis, in the excretion studies $\mathrm{C}$ and D. Urine samples were treated as described in Experimental section and analysed using a SRM method (Table 1 Method 4). The longest detected metabolite was 18-nor-17 $\beta$ hydroxymethyl-17 $\alpha$-methyl-5 $\beta$-androsta-1,4,13-triene-3-one, with detection times of 18 
and 36 days, in the $\mathrm{C}$ and $\mathrm{D}$ excretion studies, respectively. The detection time for 18 nor-dimethyl was 2.3 and 6 days, and for epimetendiol was 5 and 9 days, in the $\mathrm{C}$ and D excretion studies, respectively.

\section{Discussion}

In the present study, unaltered glucuronoconjugated metabolites of MTD were evaluated using different LC-MS/MS strategies: NL and PI scan methods and SRM methods. These strategies were defined according to characteristic ionization and CID observed for AAS glucuronides in previous studies ${ }^{[8,16]}$. The SRM method was created taking into account the expected metabolic reactions (reductions, oxidations, hydroxylations, dehydration and combination of them) and the common ionization and CID for steroid glucuronides (Table 1, Method 3).

The TIC obtained using NL and PI methods were evaluated to detect unpredicted MTD glucuronides in post-administration samples. Only one metabolite, MVII (epimetendiol $3 \alpha$-glucuronide), which is one of the most abundant metabolites of MTD ${ }^{[6]}$, was detected. XIC obtained using NL and PI methods, and SRM methods were used to detect predicted metabolites. The application of the SRM method resulted in a more sensitive methodology to detect potential metabolites (13 metabolites) (Table 2) when compared with NL and PI methods (7 metabolites) (Figure 1-S). To detect predicted metabolites using XIC, PI and NL scan methods were similar in terms of sensitivity. Moreover, the PI scan methods in positive mode were less sensitive ( 2 metabolites) than those based on PI in negative mode ( 5 metabolites), according with previous studies ${ }^{[8]}$. One of these glucuronide metabolites (MXIII) was resistant to enzymatic hydrolysis and was detected only using the SRM strategy (Table 2). 
Open scan methods are the best approach to detect unknown major metabolites, including those resulting from unforeseen metabolic pathways, when TIC data from pre- and post-administration samples can be compared. However, for unknown minor metabolites, the low sensitivity is an important limitation and, strategies for the detection of predicted metabolites (e.g., evaluation of XIC of PI and NL or SRM methods) are required. The application of these strategies needs a previous knowledge of the mass of the potential metabolites and, therefore, unexpected metabolites cannot be detected. The combination of both methodologies seems to be the most suitable approach.

In order to evaluate the interest of the detected metabolites for doping control purposes, their detection times were evaluated in four excretion studies. For AAS, the best markers of the administration are the metabolites detected for long times in urine, because they increase the detection window. For that reason, the identification work was focused on metabolites MI, MII and MVII, which were the metabolites detected for the longest period of time.

The identification of metabolites MI and MVII was performed by the chemical synthesis of the glucuronide from the corresponding phase I metabolites. Product ion mass spectra of both glucuronide metabolites are depicted in Figure 4. In positive mode, $\mathrm{m} / \mathrm{z} 269$ was the base peak for both metabolites corresponding to the loss of ammonia, glucuronide and one or two molecules of water for MI and MVII, respectively. In negative mode, characteristic ions at $m / z 75,85$ and 113 , corresponding to the glucuronide moiety, were observed in both cases. 
For metabolite MII, the identification was performed using mass spectrometric data. According to the MM, two potential candidates could be considered for MII metabolite: MTD with an oxidation (6-ene-metandienone glucuronide) or with a dehydration and a

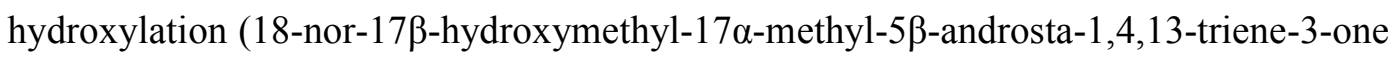
17-glucuronide) ${ }^{[6,24]}$. In ESI positive mode, a NL of formaldehyde (30 Da) is observed for steroids with a hydroxylation in a methyl group. As indicated in results section, the product ion at $m / z 269$ (resulting from the loss of the glucuronide moiety and formaldehyde) was not clearly observed in the product ion scan of MII, however the analysis of post-administration samples using the ion transition $\mathrm{m} / \mathrm{z} 475$ to $\mathrm{m} / \mathrm{z} 269$ showed a peak at the same RT of the other ion transitions of MII metabolite, confirming that ion at $m / z 269$ is formed (Figure 3). Therefore, these results suggest that metabolite MII is 18 -nor-17 $\beta$-hydroxymethyl-17 $\alpha$-methyl-5 $\beta$-androsta-1,4,13triene-3-one 17-glucuronide.

Metabolites MI, MII and MVII have been previously reported as aglycones after enzymatic hydrolysis ${ }^{[6,23,24]}$, however this is the first time that analytical data of the intact phase II metabolites are presented for some of them. Epimetendiol $3 \alpha$ glucuronide (MVII) was also previously detected as phase II metabolite by LC-MS/MS [28].

The metabolic pathways for the rest of detected metabolites (Table 2) were assigned taking into account the ionization of each metabolite, the characteristic fragmentation observed in the product ion spectrum and the common AAS metabolism previously reported. MM of metabolites MIII to MVI and MVIII are in agreement with MTD 
metabolites previously reported as aglycones. However, metabolites MIX to MXIII, which presented the highest MM have not been previously described. The MM of these metabolites indicates at least one hydroxylation, and they have short detection window (Table 2). The presence of several hydroxyl groups difficults their analysis by GC-MS, and this is probably the reason why they have not been previously detected.

The LC-MS/MS strategy allows for the detection of glucuronide metabolites resistant to hydrolysis with $\beta$-glucuronidase. Only metabolite MXIII was found to be resistant to enzymatic hydrolysis in the present study (Table 2). The MM of MXIII indicated that it is a hydroxylated metabolite of MTD, with other metabolic modifications. The detection time of MXIII in all the excretion studies was shorter than for other metabolites (up to 96h, Table 2) and, for that reason, no additional efforts were made to confirm its structure. These results illustrate that in the metabolism of MTD, the majority of the metabolites are well hydrolysed by $\beta$-glucuronidase enzyme.

In order to compare the sensitivity of the direct analysis of glucuronide metabolites by LC-MS/MS and the analysis of their corresponding aglycones by GC-MS/MS, the detection times of metabolites MI, MII and MVII and their aglycones were compared. Epimetendiol metabolite (MVII) was detected up to 5 and 9 days (in C and D excretion studies, respectively) by both technologies. 18-nor-dimethyl (MI) was detected for longest period of time by LC-MS/MS. In the case of metabolite 18-nor-17 $\beta$ hydroxymethyl-17 $\alpha$-methyl-5 $\beta$-androsta-1,4,13-triene-3-one 17-glucuronide (MII), GCMS/MS technology allowed the detection of the aglycon up to 18 and 36 days, in the C and D study, respectively; whereas the direct detection by LC-MS/MS is slightly shorter. In summary, these results show that the sensitivity obtained by each technique 
is depending on the analyte. For metabolite MII, which is the metabolite detected for longer time, the sensitivity of the GC-MS/MS method for the aglycon is better than the sensitivity of the LC-MS/MS method for the glucuronoconjugated metabolite as has been described for other AAS metabolites ${ }^{[6]}$. The high preconcentration-step using by GC-MS/MS might be also one of the reasons of the lower detection time obtained by LC-MS/MS for metabolite MII. It is worth to highlight that the detection time achieved by monitoring the sulfate conjugate of the same phase I metabolite by LC-MS/MS is longer than the observed monitoring the aglycon of the glucuronoconjugate by GCMS/MS ${ }^{[6,12]}$.

The LC-MS/MS strategy to detect glucuronoconjugated metabolites has demonstrated to be useful for MTD because a high number of potential glucuronide metabolites than those previously reported were detected. However, taking into account the detection times, the most interesting glucuronide metabolites for MTD were those previously described using GC-MS strategies ${ }^{[6,23]}$.

The LC-MS/MS strategy simplifies the analysis of glucuronoconjugated metabolites by reducing the sample preparation process, and it might be easily automatizable in the future using on-line sample preparation strategies. Methods based on the direct detection of phase II metabolites have been recently proposed to screen for AAS in sports ${ }^{[25]}$. So, although the sensitivity for some of the compounds is limited, new improvements on instrumentation and in the sample preparation process would help in the near future. 
In summary, LC-MS/MS proposed strategies have shown to be useful to directly detect unknown glucuronide MTD metabolites, including those resistant to enzymatic hydrolysis, not detectable using the conventional GC-MS strategies. Thirteen glucuronide metabolites were detected. Detection times, measured by analysis with a SRM method, were between one and twenty two days. One metabolite was resistant to hydrolysis with $\beta$-glucuronidase, however it was only detected in urine up to four days after administration. The three glucuronide metabolites detected for the longest period of time were identified by chemical synthesis or using mass spectrometric data. Although they were previously reported, this is the first time that analytical data of the intact phase II metabolites are presented for some of them.

\section{Acknowledgements}

Grants by Ministerio de Economía y Competitividad (Gobierno de España) (Project number DEP2012-35612) and Generalitat de Catalunya (Consell Català de 1'Esport and DIUE 2014 SGR 692) are gratefully acknowledged.

\section{References}

1. World Anti-doping Agency (2014). Laboratory Testing Figures. https://www.wada-ama.org/en/resources/laboratories/anti-doping-testing-figures.

2. W. Schanzer. Metabolism of anabolic androgenic steroids. Clin Chem. 1996, 42, 1001.

3. W. Schanzer, M. Donike. Metabolism of anabolic steroids in man: synthesis and use of reference substances for identification of anabolic steroid metabolites Anal Bioanal Chem. 1993, 275, 23.

4. P. Van Eenoo, F.T. Delbeke. Metabolism and excretion of anabolic steroids in doping control--new steroids and new insights. J Steroid Biochem Mol Biol. 2006, 101, 161.

5. W. Schanzer, P. Delahaut, H. Geyer, M. Machnik, S. Horning. Long-term detection and identification of metandienone and stanozolol abuse in athletes by gas chromatography-high-resolution mass spectrometry. J Chromatogr B Biomed Appl. 1996, 687, 93 .

6. W. Schanzer, H. Geyer, G. Fussholler, N. Halatcheva, M. Kohler, M.K. Parr, S. Guddat, A. Thomas, M. Thevis. Mass spectrometric identification and characterization 
of a new long-term metabolite of metandienone in human urine. Rapid Commun Mass Spectrom. 2006, 20, 2252.

7. V. Graef, E. Furuya, O. Nishikaze. Hydrolysis of steroid glucuronides with $\beta$ glucuronidase preparations from bovine liver, Helix pomatia, and E. coli. Clin Chem. 1977, 23, 532.

8. A. Fabregat, O.J. Pozo, J. Marcos, J. Segura, R. Ventura. Use of LC-MS/MS for the open detection of steroid metabolites conjugated with glucuronic acid. Anal Chem. 2013, 85, 5005 .

9. W. Schanzer, S. Guddat, A. Thomas, G. Opfermann, H. Geyer, M. Thevis. Expanding analytical possibilities concerning the detection of stanozolol misuse by means of high resolution/high accuracy mass spectrometric detection of stanozolol glucuronides in human sports drug testing. Drug Test Anal. 2013, 5, 810.

10. C. Gomez, O.J. Pozo, A. Fabregat, J. Marcos, K. Deventer, P. Van Eenoo, J. Segura, R. Ventura. Detection and characterization of urinary metabolites of boldione. Part I: phase I metabolites excreted free, as glucuronide and sulphate conjugates, and released after alkaline treatment of the urine. Drug Test Anal. 2013, 4, 775.

11. C. Gomez, O.J. Pozo, J. Marcos, J. Segura, R. Ventura. Alternative long-term markers for the detection of methyltestosterone misuse. Steroids. 2013, 78, 44.

12. C. Gomez, O.J. Pozo, L. Garrostas, J. Segura, R. Ventura. A new sulphate metabolite as a long-term marker of metandienone misuse. Steroids. 2013, 78, 1245.

13. A.G. Fragkaki, Y.S. Angelis, P. Kiousi, C.G. Georgakopoulos, E. Lyris. Comparison of sulfo-conjugated and gluco-conjugated urinary metabolites for detection of methenolone misuse in doping control by LC-HRMS, GC-MS and GC-HRMS. $J$ Mass Spectrom. 2015, 50, 740.

14. J. Lu, M. Fernandez-Alvarez, S. Yang, G. He, Y. Xu, R. Aguilera. New potential biomarkers for mesterolone misuse in human urine by liquid chromatography quadrupole time-of-flight mass spectrometry. J Mass Spectrom. 2015, 50, 153.

15. O.J. Pozo, C. Gomez, J. Marcos, J. Segura, R. Ventura. Detection and characterization of urinary metabolites of boldione by LC-MS/MS. Part II: Conjugates with cysteine and N-acetylcysteine. Drug Test Anal. 2012, 4, 786.

16. C. Gomez, A. Fabregat, O.J. Pozo, J. Marcos, J. Segura, R. Ventura. Analytical strategies based on mass spectrometric techniques for the study of steroid metabolism of steroid metabolism. TrAC. 2014, 53, 110.

17. C. Gomez, O.J. Pozo, H. Geyer, J. Marcos, M. Thevis, W. Schanzer, J. Segura, R. Ventura. New potential markers for the detection of boldenone misuse. J Steroid Biochem Mol Biol. 2012, 132, 239.

18. E.L. Rongone, A. Segaloff. In vivo metabolism of $\Delta^{1}, 17 \alpha$-methyltestosterone in man. Steroids. 1963, 1, 179.

19. H.W. Durbeck, I. Buker. Studies on anabolic steroids. The mass spectra of $17 \alpha-$ methyl-17ß-hydroxy-1,4-androstadien-3-one (Dianabol) and its metabolites. Biomed Mass Spectrom. 1980, 7, 437.

20. H.W. Durbeck, I. Buker, B. Scheulen, B. Telin. Gas chromatographic and capillary column gas chromatographic--mass spectrometric determination of synthetic anabolic steroids. I. Methandienone and its metabolites. J Chromatogr. 1978, 167, 117.

21. R. Masse, H.G. Bi, C. Ayotte, P. Du, H. Gelinas, R. Dugal. Studies on anabolic steroids. V. Sequential reduction of methandienone and structurally related steroid Aring substituents in humans: gas chromatographic-mass spectrometric study of the corresponding urinary metabolites. J Chromatogr. 1991, 562, 323. 
22. H. Bi, R. Masse. Studies on anabolic steroids--12. Epimerization and degradation of anabolic $17 \beta$-sulfate-17 $\alpha$-methyl steroids in human: qualitative and quantitative GC/MS analysis. J Steroid Biochem Mol Biol. 1992, 42, 533.

23. W. Schanzer, H. Geyer, M. Donike. Metabolism of metandienone in man: identification and synthesis of conjugated excreted urinary metabolites, determination of excretion rates and gas chromatographic-mass spectrometric identification of bishydroxylated metabolites. J Steroid Biochem Mol Biol. 1991, 38, 441.

24. A. Zollner, M.K. Parr, C.A. Dragan, S. Dras, N. Schlorer, F.T. Peters, H.H. Maurer, W. Schanzer, M. Bureik. CYP21-catalyzed production of the long-term urinary metandienone metabolite $17 \beta$-hydroxymethyl-17 $\alpha$-methyl-18-norandrosta-1,4,13-trien3-one: a contribution to the fight against doping. Biol Chem. 2010, 391, 119.

25. G. Balcells, O.J. Pozo, A. Esquivel, A. Kotronoulas, J. Joglar, J. Segura, R. Ventura. Screening for anabolic steroids in sports: analytical strategy based on the detection of phase I and phase II intact urinary metabolites by liquid chromatography tandem mass spectrometry. J Chromatogr A. 2015, 1389, 65.

26. M.A. Delgadillo, L. Garrostas, O.J. Pozo, R. Ventura, B. Velasco, J. Segura, J. Marcos. Sensitive and robust method for anabolic agents in human urine by gas chromatography-triple quadrupole mass spectrometry. J Chromatogr B Analyt Technol Biomed Life Sci. 2012, 897, 85.

27. A. Kotronoulas, A. Fabregat, I. Alfonso, T. Parella, J. Segura, R. Ventura, J. Joglar, O.J. Pozo. Synthesis and characterization of $6 \beta$-hydroxyandrosterone and $6 \beta$ hydroxyetiocholanolone conjugated with glucuronic acid. Drug Test Anal. 2015, 7, 247. 28. L. Hintikka, T. Kuuranne, A. Leinonen, M. Thevis, W. Schanzer, J. Halket, D. Cowan, J. Grosse, P. Hemmersbach, M.W. Nielen, R. Kostiainen. Liquid chromatographic-mass spectrometric analysis of glucuronide-conjugated anabolic steroid metabolites: method validation and interlaboratory comparison. $J$ Mass Spectrom. 2008, 43, 965. 


\section{FIGURE LEGENDS}

Figure 1. Results of the administration study C of MTD: chromatograms of the characteristic ion transitions of the metabolites detected after analysis of a preadministration sample (day 0) and samples collected at 8h, 48h, 4 and 14 days after MTD oral administration. Chromatograms are scaled to the last sample in which the metabolite was detected.

Figure 2. Detection times of metabolites detected in four excretion studies after oral administration of MTD obtained by LC-MS/MS

Figure 3. LC-MS/MS identification of metabolites MI, MVII and MII. Chromatograms of characteristics ion transitions for metabolites in: (a) pre-administration sample; (b) sample collected 48h after MTD administration; and (c) synthesized products.

Figure 4. Product ion scan of synthesized products of: MI glucuronide (in positive mode at $\mathrm{CV}=15 \mathrm{~V}$ and $\mathrm{CE}=30 \mathrm{eV}$; in negative mode at $\mathrm{CV}=25 \mathrm{~V}$ and $\mathrm{CE}=40 \mathrm{eV}$ ) and MVII glucuronide (in positive mode at $\mathrm{CV}=25 \mathrm{~V}$ and $\mathrm{CE}=35 \mathrm{eV}$; in negative mode at $\mathrm{CV}=55 \mathrm{~V}$ and $\mathrm{CE}=40 \mathrm{eV})$. 
Table 1. Mass spectrometric methods applied during the study. Parameters: CV (cone voltage), CE (collision energy), PI (precursor ion), DI (product ion), ox: oxidation; red: reduction; OH: hydroxylation; dehy: dehydration.

\begin{tabular}{|c|c|c|c|c|c|c|c|}
\hline \multicolumn{8}{|l|}{$\begin{array}{l}\text { Method } 1 \\
\text { (LC-MS/MS) }\end{array}$} \\
\hline Scan Mode & Ionization mode & \multicolumn{3}{|c|}{ Neutral loss (Da) } & $\begin{array}{l}\text { CV } \\
(V)\end{array}$ & $\begin{array}{l}\mathrm{CE} \\
(\mathrm{eV})\end{array}$ & $\begin{array}{l}\text { Range } \\
(\mathbf{m} / \mathbf{z})\end{array}$ \\
\hline NL & ESI+ & \multicolumn{3}{|c|}{$\begin{array}{l}{[\mathrm{M}+\mathrm{H} \text {-gluc }]^{+}} \\
{\left[\mathrm{M}+\mathrm{H} \text {-gluc- } \mathrm{H}_{2} \mathrm{O}\right]^{+}} \\
{\left[\mathrm{M}+\mathrm{NH}_{4}-\mathrm{NH}_{3}-\text { gluc- } \mathrm{H}_{2} \mathrm{O}\right]^{+}} \\
{\left[\mathrm{M}+\mathrm{NH}_{4}-\mathrm{NH}_{3}-\text { gluc- } 2 \mathrm{H}_{2} \mathrm{O}\right]^{+}}\end{array}$} & $\begin{array}{l}20 \\
20 \\
20 \\
20\end{array}$ & $\begin{array}{l}20 \\
20 \\
20 \\
20\end{array}$ & $\begin{array}{l}450-600 \\
450-600 \\
450-600 \\
450-600\end{array}$ \\
\hline \multicolumn{8}{|l|}{$\begin{array}{l}\text { Method 2 } \\
\text { (LC-MS/MS) }\end{array}$} \\
\hline Scan Mode & Ionization mode & \multicolumn{3}{|c|}{ Precursor ion $(\mathrm{m} / \mathrm{z})$} & $\begin{array}{l}\text { CV } \\
\text { (V) }\end{array}$ & $\begin{array}{l}\mathrm{CE} \\
(\mathrm{eV})\end{array}$ & $\begin{array}{l}\text { Range } \\
(\mathbf{m} / \mathbf{z})\end{array}$ \\
\hline PI & ESI- & \multicolumn{2}{|c|}{ 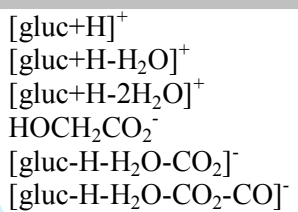 } & $\begin{array}{l}141 \\
159 \\
177 \\
75 \\
85 \\
113\end{array}$ & $\begin{array}{l}20 \\
20 \\
20 \\
20 \\
20 \\
20\end{array}$ & $\begin{array}{l}30 \\
20 \\
20 \\
40 \\
40 \\
40\end{array}$ & $\begin{array}{l}450-600 \\
450-600 \\
450-600 \\
450-600 \\
450-600 \\
450-600 \\
\end{array}$ \\
\hline \multicolumn{8}{|l|}{$\begin{array}{l}\text { Method 3 } \\
\text { (LC-MS/MS) }\end{array}$} \\
\hline Scan Mode & $\begin{array}{l}\text { Metabolic pathways of the } \\
\text { phase I metabolites }\end{array}$ & \multicolumn{2}{|c|}{ PI (m/z) } & \multicolumn{2}{|l|}{$\begin{array}{c}\text { DI } \\
(\mathrm{m} / \mathrm{z})\end{array}$} & CV (V) & CE $(\mathrm{eV})$ \\
\hline \multirow[t]{14}{*}{ SRM } & 2 red +1 dehy* & $\begin{array}{l}{[\mathrm{M}+\mathrm{H}]^{+}} \\
{\left[\mathrm{M}+\mathrm{NH}_{4}\right]^{+}} \\
{[\mathrm{M}-\mathrm{H}]^{-}}\end{array}$ & $\begin{array}{l}463 \\
480 \\
461\end{array}$ & $\begin{array}{l}{[\mathrm{M}+\mathrm{H}-176]^{+}} \\
{\left[\mathrm{M}+\mathrm{NH}_{4}-229\right]^{+}} \\
\mathrm{HOCH}_{2} \mathrm{CO}_{2}^{-}\end{array}$ & $\begin{array}{l}287 \\
251 \\
75\end{array}$ & $\begin{array}{l}25 \\
20 \\
55\end{array}$ & $\begin{array}{l}45 \\
25 \\
35\end{array}$ \\
\hline & 3red+1dehy & $\begin{array}{l}{[\mathrm{M}+\mathrm{H}]^{+}} \\
{\left[\mathrm{M}+\mathrm{NH}_{4}\right]^{+}} \\
{[\mathrm{M}-\mathrm{H}]^{-}}\end{array}$ & $\begin{array}{l}465 \\
482 \\
463\end{array}$ & $\begin{array}{l}{[\mathrm{M}+\mathrm{H}-176]^{+}} \\
{\left[\mathrm{M}+\mathrm{NH}_{4}-229\right]^{+}} \\
\mathrm{HOCH}_{2} \mathrm{CO}_{2}^{-}\end{array}$ & $\begin{array}{l}289 \\
253 \\
75\end{array}$ & $\begin{array}{l}25 \\
20 \\
55\end{array}$ & $\begin{array}{l}45 \\
25 \\
35\end{array}$ \\
\hline & $\begin{array}{c}\text { 1ox or } \\
1 \mathrm{OH}+1 \text { dehy* }\end{array}$ & $\begin{array}{l}{[\mathrm{M}+\mathrm{H}]^{+}} \\
{\left[\mathrm{M}+\mathrm{NH}_{4}\right]^{+}} \\
{[\mathrm{M}-\mathrm{H}]^{-}}\end{array}$ & $\begin{array}{l}475 \\
492 \\
473\end{array}$ & $\begin{array}{l}{[\mathrm{M}+\mathrm{H}-176]^{+}} \\
{\left[\mathrm{M}+\mathrm{NH}_{4}-229\right]^{+}} \\
\mathrm{HOCH}_{2} \mathrm{CO}_{2}^{-}\end{array}$ & $\begin{array}{l}299 \\
263 \\
75\end{array}$ & $\begin{array}{l}25 \\
20 \\
55\end{array}$ & $\begin{array}{l}45 \\
25 \\
35\end{array}$ \\
\hline & $\begin{array}{c}\text { MTD* or } \\
1 \mathrm{OH}+1 \mathrm{red}+1 \text { dehy* }\end{array}$ & $\begin{array}{l}{[\mathrm{M}+\mathrm{H}]^{+}} \\
{\left[\mathrm{M}+\mathrm{NH}_{4}\right]^{+}} \\
{[\mathrm{M}-\mathrm{H}]^{-}}\end{array}$ & $\begin{array}{l}477 \\
494 \\
475\end{array}$ & $\begin{array}{l}{[\mathrm{M}+\mathrm{H}-176]^{+}} \\
{\left[\mathrm{M}+\mathrm{NH}_{4}-229\right]^{+}} \\
\mathrm{HOCH}_{2} \mathrm{CO}_{2}^{-}\end{array}$ & $\begin{array}{l}301 \\
265 \\
75\end{array}$ & $\begin{array}{l}25 \\
20 \\
55\end{array}$ & $\begin{array}{l}45 \\
25 \\
35\end{array}$ \\
\hline & $\begin{array}{c}1 \text { red* or } \\
1 \mathrm{OH}+2 \mathrm{red}+1 \text { dehy* }\end{array}$ & $\begin{array}{l}{[\mathrm{M}+\mathrm{H}]^{+}} \\
{\left[\mathrm{M}+\mathrm{NH}_{4}\right]^{+}} \\
{[\mathrm{M}-\mathrm{H}]^{-}}\end{array}$ & $\begin{array}{l}479 \\
496 \\
477\end{array}$ & $\begin{array}{l}{[\mathrm{M}+\mathrm{H}-176]^{+}} \\
{\left[\mathrm{M}+\mathrm{NH}_{4}-229\right]^{+}} \\
\mathrm{HOCH}_{2} \mathrm{CO}_{2}^{-}\end{array}$ & $\begin{array}{l}303 \\
267 \\
75\end{array}$ & $\begin{array}{l}25 \\
20 \\
55\end{array}$ & $\begin{array}{l}45 \\
25 \\
35\end{array}$ \\
\hline & $\begin{array}{c}2 \text { red* or }^{*} \\
1 \mathrm{OH}+3 \mathrm{red}+1 \text { dehy }\end{array}$ & $\begin{array}{l}{[\mathrm{M}+\mathrm{H}]^{+}} \\
{\left[\mathrm{M}+\mathrm{NH}_{4}\right]^{+}} \\
{[\mathrm{M}-\mathrm{H}]^{-}}\end{array}$ & $\begin{array}{l}481 \\
498 \\
479\end{array}$ & $\begin{array}{l}{[\mathrm{M}+\mathrm{H}-176]^{+}} \\
{\left[\mathrm{M}+\mathrm{NH}_{4}-229\right]^{+}} \\
\mathrm{HOCH}_{2} \mathrm{CO}_{2}^{-}\end{array}$ & $\begin{array}{l}305 \\
269 \\
75 \\
\end{array}$ & $\begin{array}{l}25 \\
20 \\
55 \\
\end{array}$ & $\begin{array}{l}45 \\
25 \\
35 \\
\end{array}$ \\
\hline & 3red & $\begin{array}{l}{[\mathrm{M}+\mathrm{H}]^{+}} \\
{\left[\mathrm{M}+\mathrm{NH}_{4}\right]^{+}} \\
{[\mathrm{M}-\mathrm{H}]^{-}}\end{array}$ & $\begin{array}{l}483 \\
500 \\
481 \\
\end{array}$ & $\begin{array}{l}{[\mathrm{M}+\mathrm{H}-176]^{+}} \\
{\left[\mathrm{M}+\mathrm{NH}_{4}-229\right]^{+}} \\
\mathrm{HOCH}_{2} \mathrm{CO}_{2}^{-}\end{array}$ & $\begin{array}{l}307 \\
271 \\
75\end{array}$ & $\begin{array}{l}25 \\
20 \\
55\end{array}$ & $\begin{array}{l}45 \\
25 \\
35 \\
\end{array}$ \\
\hline & $2 \mathrm{OH}+1 \mathrm{ox}+1$ dehy & $\begin{array}{l}{[\mathrm{M}+\mathrm{H}]^{+}} \\
{\left[\mathrm{M}+\mathrm{NH}_{4}\right]^{+}} \\
{[\mathrm{M}-\mathrm{H}]^{-}}\end{array}$ & $\begin{array}{l}489 \\
506 \\
487\end{array}$ & $\begin{array}{l}{[\mathrm{M}+\mathrm{H}-176]^{+}} \\
{\left[\mathrm{M}+\mathrm{NH}_{4}-229\right]^{+}} \\
\mathrm{HOCH}_{2} \mathrm{CO}_{2}^{-}\end{array}$ & $\begin{array}{l}313 \\
277 \\
75\end{array}$ & $\begin{array}{l}25 \\
20 \\
55\end{array}$ & $\begin{array}{l}45 \\
25 \\
35\end{array}$ \\
\hline & $\begin{array}{l}1 \mathrm{OH}+1 \text { ox or } \\
2 \mathrm{OH}+1 \text { dehy* }\end{array}$ & $\begin{array}{l}{[\mathrm{M}+\mathrm{H}]^{+}} \\
{\left[\mathrm{M}+\mathrm{NH}_{4}\right]^{+}} \\
{[\mathrm{M}-\mathrm{H}]^{-}}\end{array}$ & $\begin{array}{l}491 \\
508 \\
489\end{array}$ & $\begin{array}{l}\mathrm{M}+\mathrm{H}-176]^{+} \\
{\left[\mathrm{M}+\mathrm{NH}_{4}-229\right]^{+}} \\
\mathrm{HOCH}_{2} \mathrm{CO}_{2}^{-}\end{array}$ & $\begin{array}{l}315 \\
279 \\
75\end{array}$ & $\begin{array}{l}25 \\
20 \\
55\end{array}$ & $\begin{array}{l}45 \\
25 \\
35\end{array}$ \\
\hline & $\begin{array}{c}1 \mathrm{OH}^{*} \text { or } \\
2 \mathrm{OH}+1 \mathrm{red}+1 \text { dehy* }\end{array}$ & $\begin{array}{l}{[\mathrm{M}+\mathrm{H}]^{+}} \\
{\left[\mathrm{M}+\mathrm{NH}_{4}\right]^{+}} \\
{[\mathrm{M}-\mathrm{H}]^{-}}\end{array}$ & $\begin{array}{l}493 \\
510 \\
491\end{array}$ & $\begin{array}{l}{[\mathrm{M}+\mathrm{H}-176]^{+}} \\
{\left[\mathrm{M}+\mathrm{NH}_{4}-229\right]^{+}} \\
\mathrm{HOCH}_{2} \mathrm{CO}_{2}^{-}\end{array}$ & $\begin{array}{l}317 \\
281 \\
75\end{array}$ & $\begin{array}{l}25 \\
20 \\
55\end{array}$ & $\begin{array}{l}45 \\
25 \\
35\end{array}$ \\
\hline & $\begin{array}{c}1 \mathrm{OH}+1 \mathrm{red}^{*} \text { or } \\
2 \mathrm{OH}+2 \mathrm{red}+1 \text { dehy* }\end{array}$ & $\begin{array}{l}{[\mathrm{M}+\mathrm{H}]^{+}} \\
{\left[\mathrm{M}+\mathrm{NH}_{4}\right]^{+}} \\
{[\mathrm{M}-\mathrm{H}]^{-}}\end{array}$ & $\begin{array}{l}495 \\
512 \\
493 \\
\end{array}$ & $\begin{array}{l}{[\mathrm{M}+\mathrm{H}-176]^{+}} \\
{\left[\mathrm{M}+\mathrm{NH}_{4}-229\right]^{+}} \\
\mathrm{HOCH}_{2} \mathrm{CO}_{2}^{-}\end{array}$ & $\begin{array}{l}319 \\
283 \\
75 \\
\end{array}$ & $\begin{array}{l}25 \\
20 \\
55 \\
\end{array}$ & $\begin{array}{l}45 \\
25 \\
35 \\
\end{array}$ \\
\hline & $1 \mathrm{OH}+2$ red* or $^{*}$ & {$[\mathrm{M}+\mathrm{H}]^{+}$} & 497 & {$[\mathrm{M}+\mathrm{H}-176]^{+}$} & 321 & 25 & 45 \\
\hline & $2 \mathrm{OH}+3 \mathrm{red}+1 \mathrm{dehy}$ & {$\left[\mathrm{M}+\mathrm{NH}_{4}\right]^{+}$} & 514 & {$\left[\mathrm{M}+\mathrm{NH}_{4}-229\right]^{+}$} & 285 & 20 & 25 \\
\hline & & {$[\mathrm{M}-\mathrm{H}]^{-}$} & 495 & $\mathrm{HOCH}_{2} \mathrm{CO}_{2}^{-}$ & 75 & 55 & 35 \\
\hline
\end{tabular}




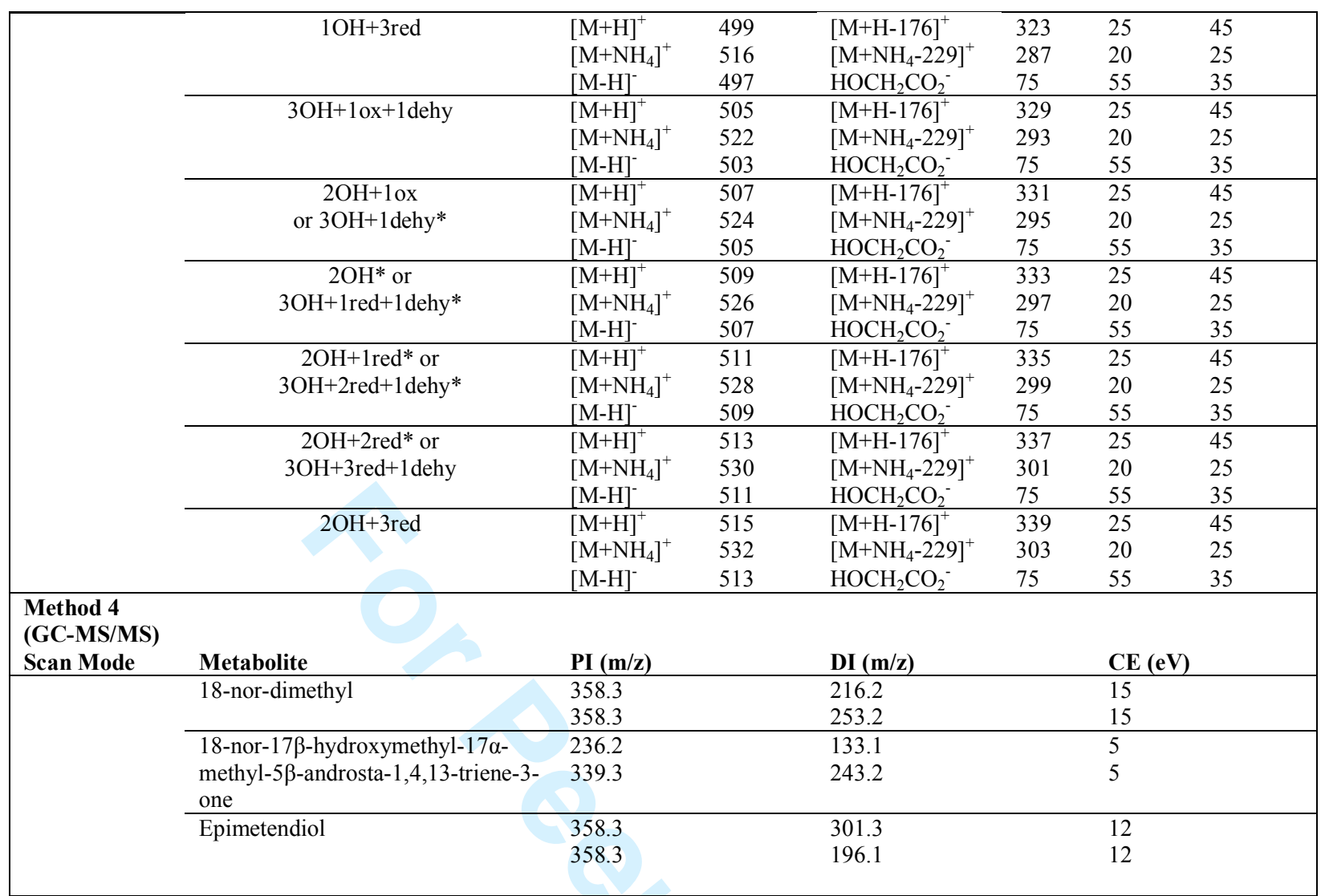

*Each MM can correspond to a metabolite resulting from the metabolic modification(s) shown in the table, or to a metabolite combining an additional and equal number of reductions and oxidations. 
Table 2. Glucuronoconjugated MTD metabolites detected in excretion study samples. Metabolic pathway, molecular mass (MM), retention time (RT), monitoring conditions and detection times in four excretion studies.

\begin{tabular}{|c|c|c|c|c|c|c|c|c|}
\hline \multirow[b]{2}{*}{ Code } & \multirow{2}{*}{$\begin{array}{c}\text { Metabolic } \\
\text { pathways of the } \\
\text { phase I } \\
\text { metabolites }\end{array}$} & \multirow[b]{2}{*}{$\begin{array}{l}\text { MM } \\
\text { (Da) }\end{array}$} & \multirow[b]{2}{*}{$\begin{array}{c}\text { RT } \\
(\min )\end{array}$} & \multirow[b]{2}{*}{$\begin{array}{c}\text { Ion transition } \\
(\mathrm{CV}(\mathrm{V}), \mathrm{CE}(\mathrm{eV}))\end{array}$} & \multicolumn{4}{|c|}{ Detection time (days) } \\
\hline & & & & & $\begin{array}{c}\text { Excretion } \\
\text { study A }\end{array}$ & $\begin{array}{l}\text { Excretion } \\
\text { study B }\end{array}$ & $\begin{array}{l}\text { Excretion } \\
\text { study C }\end{array}$ & $\begin{array}{c}\text { Excretion } \\
\text { study D }\end{array}$ \\
\hline MI & 2 red+1dehy & 462 & 32.89 & $\begin{array}{c}\mathbf{4 8 0}>\mathbf{2 6 9}(\mathbf{2 0}, \mathbf{2 5}) \\
461>75(55,35) \\
461>85(55,35)\end{array}$ & 3 & 5 & 4 & 11 \\
\hline MII & $\begin{array}{c}1 \mathrm{OH}+\text { dehy or } \\
1 \mathrm{ox}\end{array}$ & 474 & 11.10 & $\begin{array}{l}\mathbf{4 7 5}>147(25,20) \\
475>171(25,35) \\
475>173(20,40)\end{array}$ & 3 & 10 & 14 & 22 \\
\hline MIII & \multirow[b]{2}{*}{$\begin{array}{c}1 \text { red }^{*} \text { or } \\
1 \mathrm{OH}+2 \mathrm{red}+1 \text { dehy* }\end{array}$} & \multirow[b]{2}{*}{478} & 26.31 & $\begin{array}{c}\mathbf{4 7 7}>\mathbf{8 5}(\mathbf{5 5}, \mathbf{4 0}) \\
477>113(55,30) \\
477>75(55,40)\end{array}$ & 1 & 3 & 4 & 5 \\
\hline MIV & & & 32.10 & $\begin{array}{c}\mathbf{4 9 6}>\mathbf{2 6 7}(\mathbf{2 5}, \mathbf{2 0}) \\
477>75(55,30) \\
477>85(55,30)\end{array}$ & 3 & 5 & 4 & 3,3 \\
\hline MV & \multirow{4}{*}{$\begin{array}{c}2 \text { red* or }^{*} \text { or } \\
1 \mathrm{OH}+3 \mathrm{red}+1 \text { dehy }\end{array}$} & \multirow{2}{*}{480} & 14.26 & $\begin{array}{c}\mathbf{4 7 9}>75(\mathbf{5 5}, \mathbf{3 0}) \\
479>113(55,30) \\
479>85(55,30)\end{array}$ & 3 & 3 & 2,3 & 5 \\
\hline MVI & & & 15.02 & $\begin{array}{c}\mathbf{4 7 9}>\mathbf{7 5}(\mathbf{5 5}, \mathbf{3 0}) \\
479>85(55,30) \\
479>113(55,30)\end{array}$ & 2 & 2 & 1 & 2,3 \\
\hline MVII & & \multirow{2}{*}{480} & 26.06 & $\begin{array}{c}\mathbf{4 9 8}>\mathbf{2 6 9}(\mathbf{2 5}, \mathbf{2 0}) \\
479>85(55,40) \\
479>75(55,30)\end{array}$ & 3 & 6 & 4 & 9 \\
\hline MVIII & & & 26.50 & $\begin{array}{c}\mathbf{4 9 8}>\mathbf{2 6 9}(\mathbf{2 5}, \mathbf{2 0}) \\
479>75(55,30) \\
479>85(55,40)\end{array}$ & 2 & 3 & 2,3 & 2,3 \\
\hline MIX & $1 \mathrm{OH}$ & \multirow{2}{*}{492} & 3.79 & $\begin{array}{c}\mathbf{4 9 1}>\mathbf{3 1 5}(\mathbf{5 5}, \mathbf{3 0}) \\
491>113(55,30) \\
491>75(55,30)\end{array}$ & 1,5 & 2 & 1,5 & 1,5 \\
\hline MX & $2 \mathrm{OH}+1 \mathrm{red}+1$ dehy & & 5.28 & $\begin{array}{c}\mathbf{4 9 1}>\mathbf{1 1 3}(\mathbf{5 5}, \mathbf{3 0}) \\
491>75(55,30) \\
491>315(55,30) \\
\end{array}$ & 1 & nd & 1 & 1 \\
\hline MXI & $\begin{array}{c}1 \mathrm{OH}+2 \mathrm{red}^{*} \text { or } \\
2 \mathrm{OH}+3 \mathrm{red}+1 \text { dehy }\end{array}$ & 496 & 9.04 & $\begin{array}{c}\mathbf{4 9 5}>\mathbf{7 5}(\mathbf{5 5}, \mathbf{4 0}) \\
495>113(55,30) \\
495>85(55,30)\end{array}$ & 3 & 3 & 3 & 5 \\
\hline MXII & \multirow{2}{*}{$\begin{array}{c}2 \mathrm{OH}+1 \mathrm{red}^{*} \text { or } \\
3 \mathrm{OH}+2 \mathrm{red}+1 \text { dehy* }\end{array}$} & \multirow{2}{*}{510} & 1.74 & $\begin{array}{c}\mathbf{5 0 9}>\mathbf{1 1 3}(\mathbf{5 5}, \mathbf{3 0}) \\
509>75(55,30) \\
509>333(55,40)\end{array}$ & 1 & 2 & 1 & 1 \\
\hline MXIII & & & 2.04 & $\begin{array}{c}\mathbf{5 0 9}>\mathbf{3 3 3}(\mathbf{5 5}, \mathbf{4 0}) \\
509>75(55,30) \\
509>113(55,30)\end{array}$ & 3 & 4 & 3 & 2 \\
\hline
\end{tabular}

*Each MM can correspond to a metabolite resulting from the metabolic modification(s) shown in the table, or to a metabolite combining an additional and equal number of reductions and oxidations. 
Figure 1. Results of the administration study C of MTD: chromatograms of the characteristic ion transitions of the metabolites detected after analysis of a pre-administration sample (day 0) and samples collected at 8h, 48h, 4 and 14 days after MTD oral administration. Chromatograms are scaled to the last sample in which the metabolite was detected.

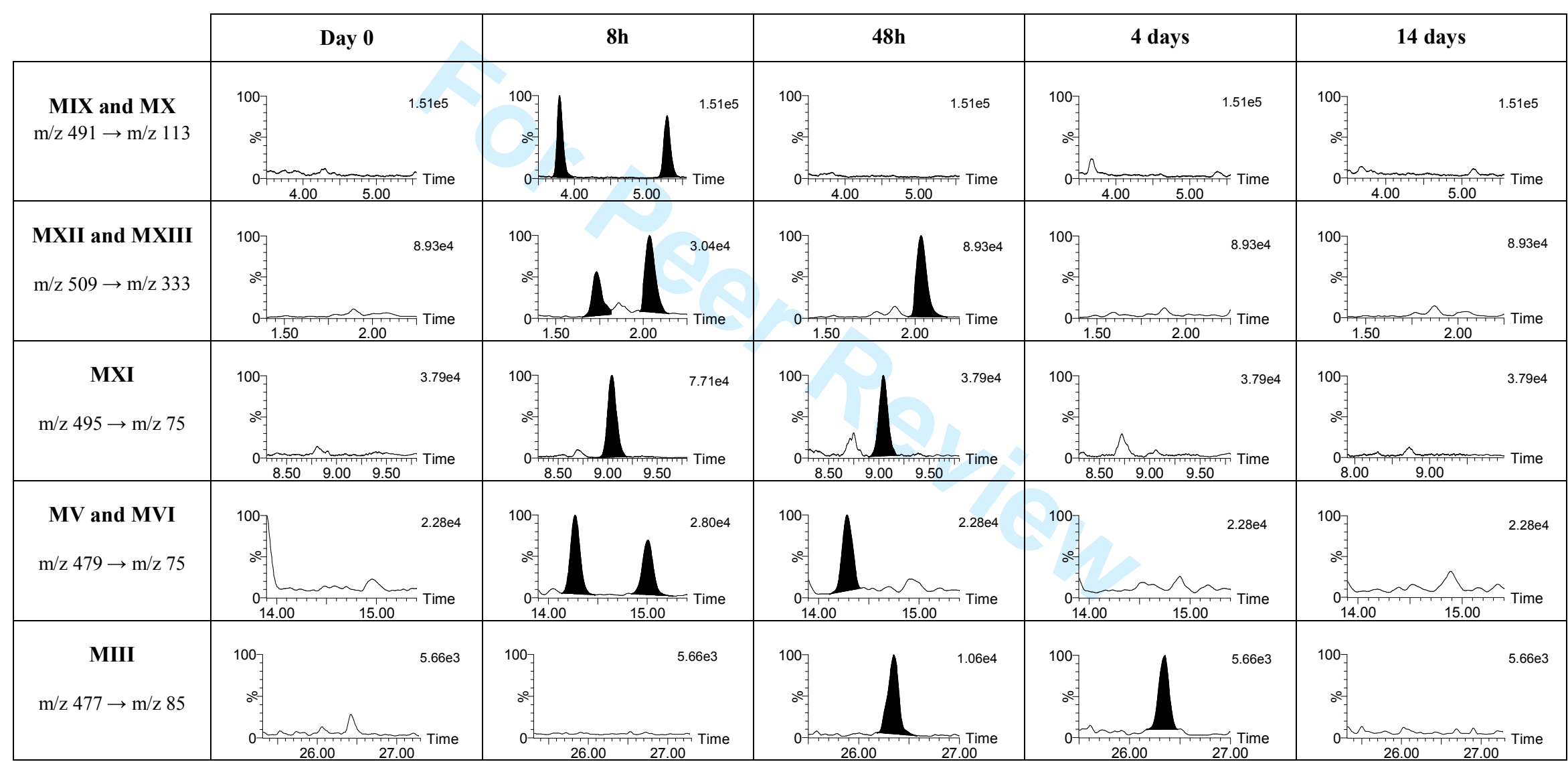




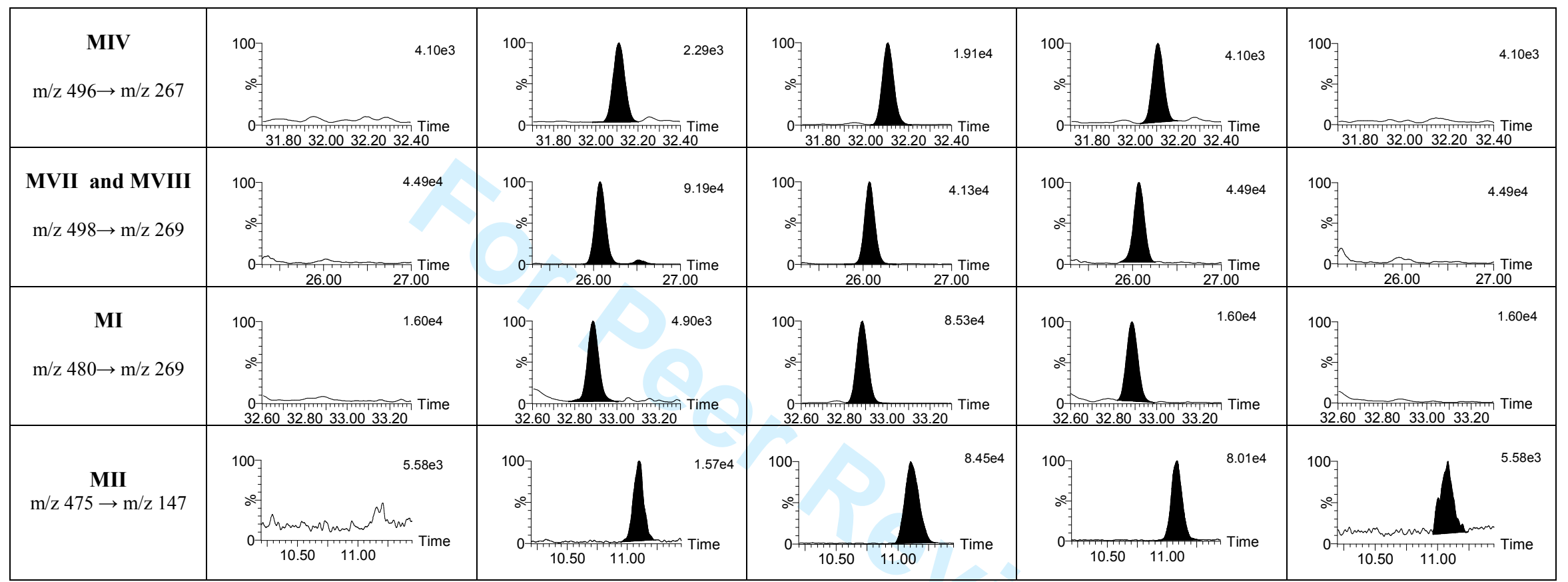


Figure 2. Detection times of metabolites detected in four excretion studies after oral administration of MTD obtained by LC-MS/MS.

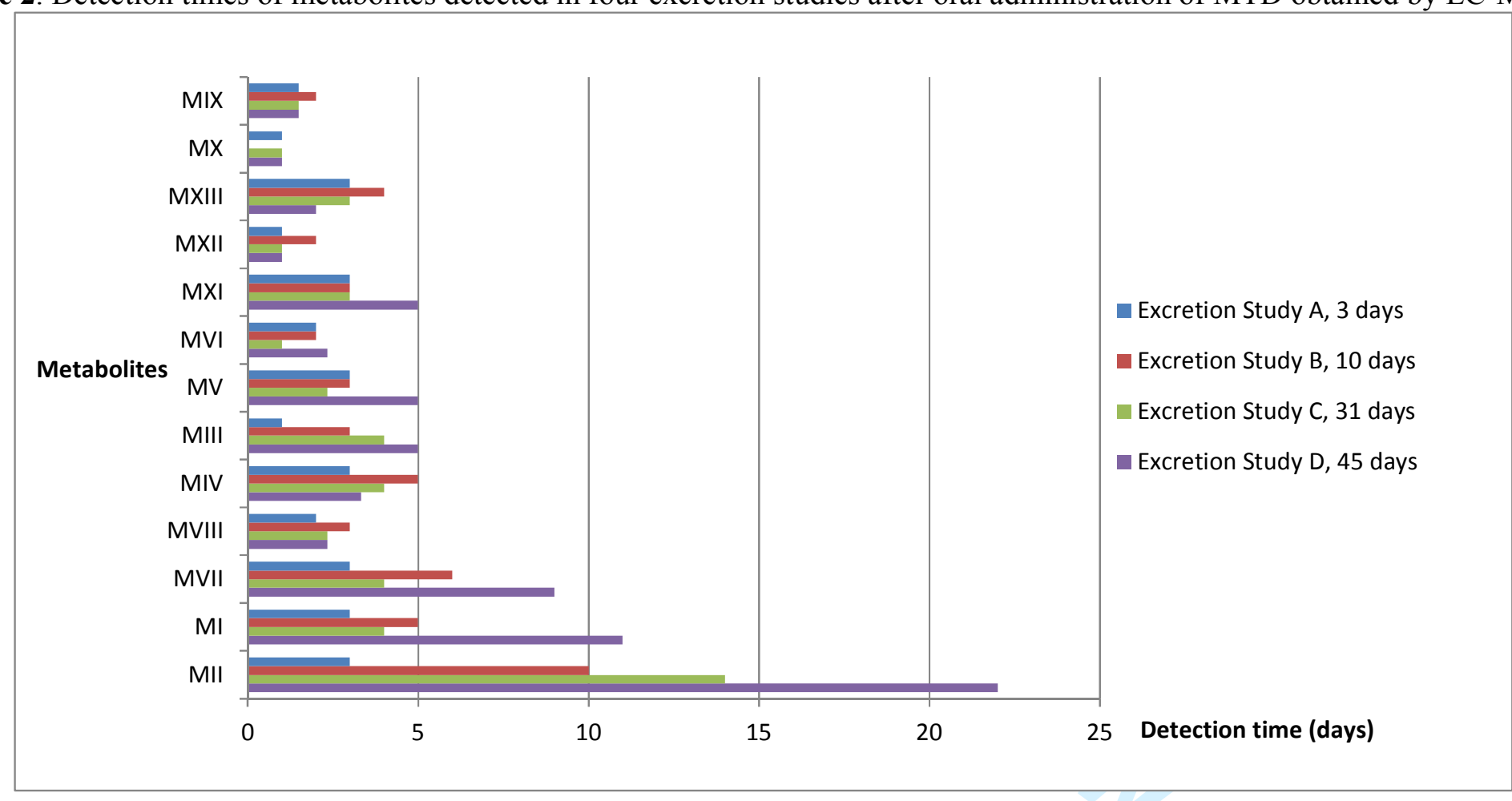


Figure 3. LC-MS/MS identification of metabolites MI, MVII and MII. Chromatograms of characteristics ion transitions for metabolites in: (a) pre-administration sample; (b) sample collected 48h after MTD administration; and (c) synthesized products.

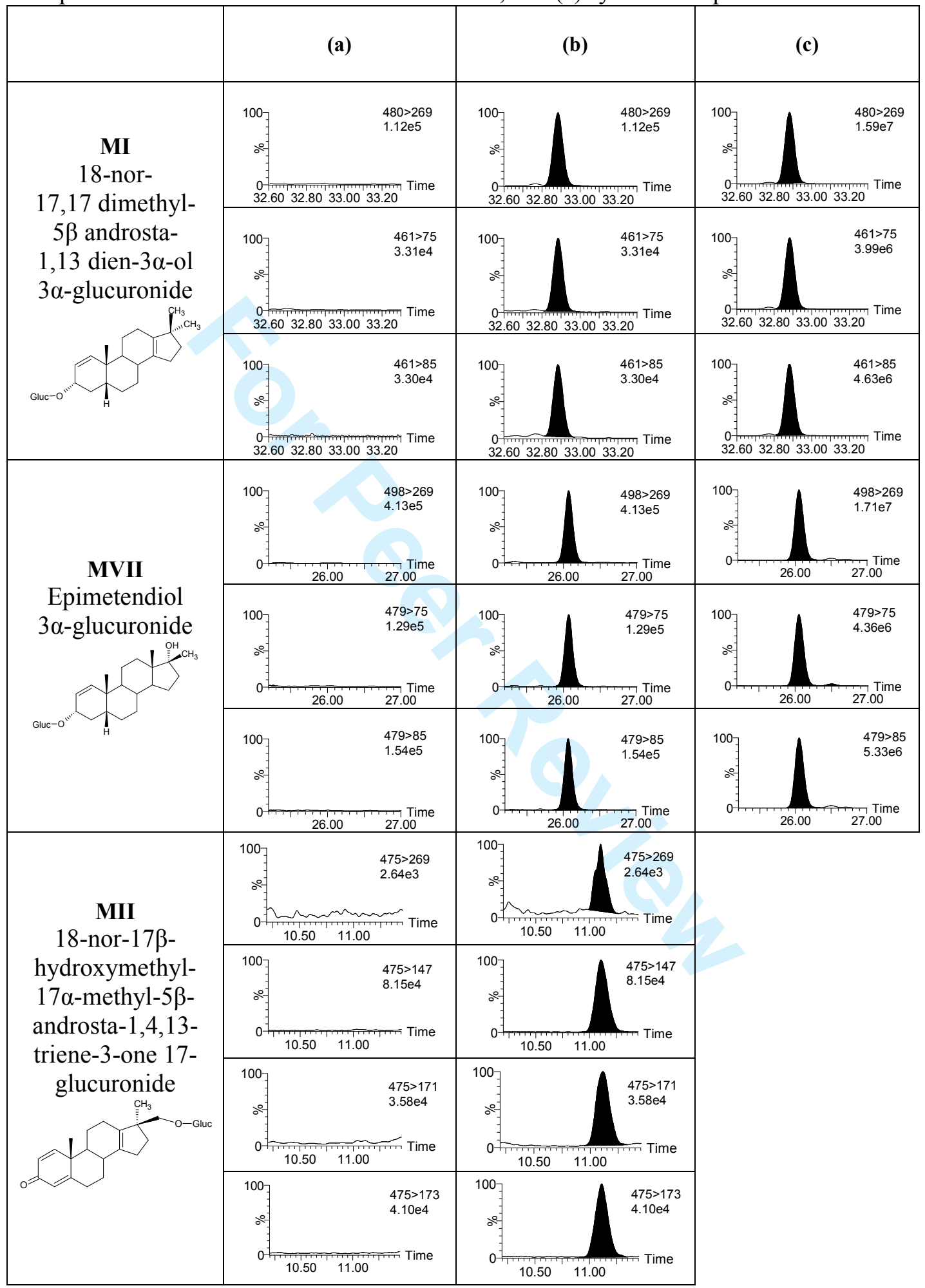


Figure 4. Product ion scan of synthesized products of: MI glucuronide (in positive mode at $\mathrm{CV}=15 \mathrm{~V}$ and $\mathrm{CE}=30 \mathrm{eV}$; in negative mode at $\mathrm{CV}=25 \mathrm{~V}$ and $\mathrm{CE}=40 \mathrm{eV}$ ) and MVII glucuronide (in positive mode at $\mathrm{CV}=25 \mathrm{~V}$ and $\mathrm{CE}=35 \mathrm{eV}$; in negative mode at $\mathrm{CV}=55 \mathrm{~V}$ and $\mathrm{CE}=40 \mathrm{eV})$.

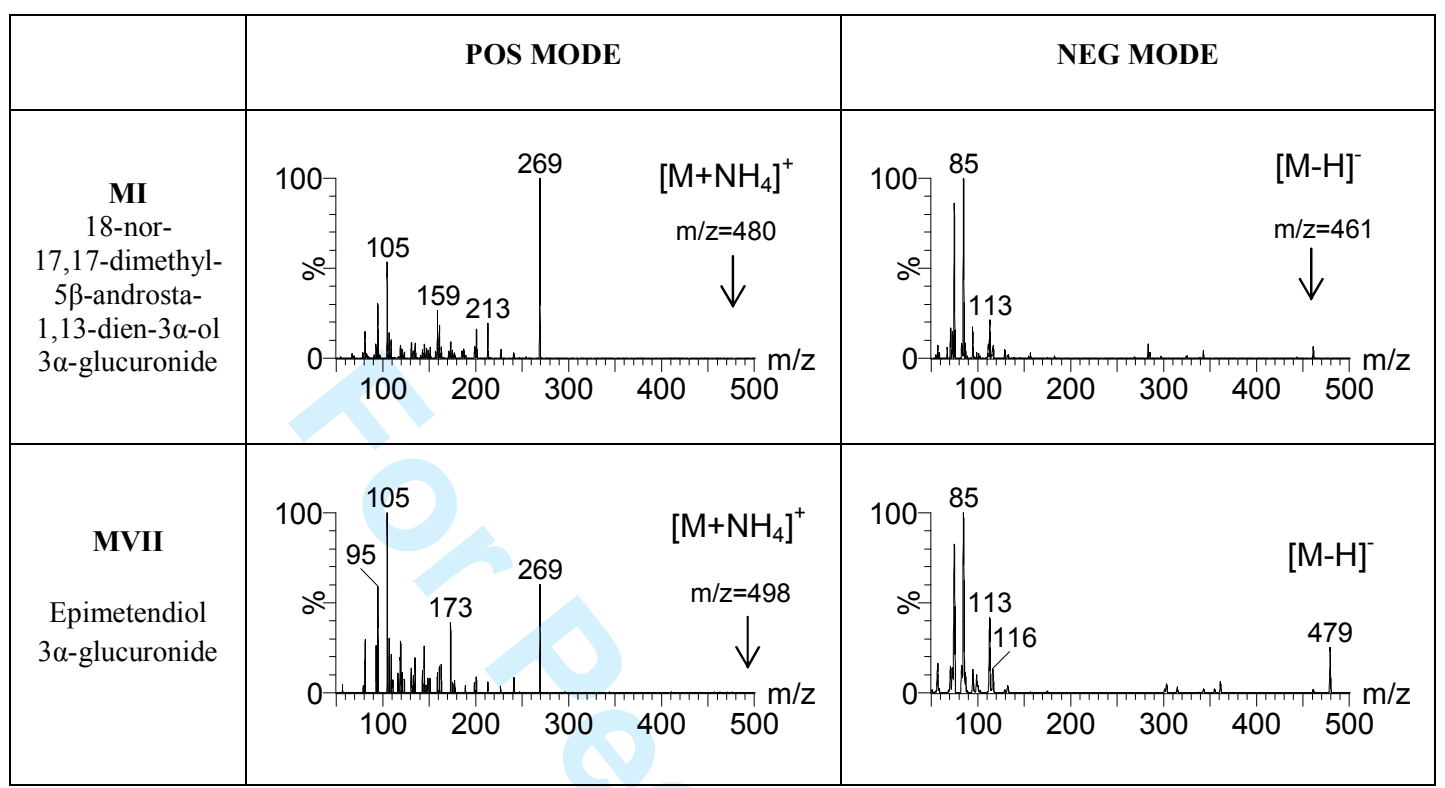

